\title{
Frankston Phase Ceramics from the Alcoa \#1 (41AN87) Site, Mound Prairie Creek, Anderson County, Texas
}

Timothy K. Perttula

Heritage Research Center, Stephen F. Austin State University

Follow this and additional works at: https://scholarworks.sfasu.edu/ita

Part of the American Material Culture Commons, Archaeological Anthropology Commons, Environmental Studies Commons, Other American Studies Commons, Other Arts and Humanities Commons, Other History of Art, Architecture, and Archaeology Commons, and the United States History Commons

Tell us how this article helped you.

This Article is brought to you for free and open access by the Center for Regional Heritage Research at SFA ScholarWorks. It has been accepted for inclusion in Index of Texas Archaeology: Open Access Gray Literature from the Lone Star State by an authorized editor of SFA ScholarWorks. For more information, please contact cdsscholarworks@sfasu.edu. 
Frankston Phase Ceramics from the Alcoa \#1 (41AN87) Site, Mound Prairie Creek, Anderson County, Texas

\section{Creative Commons License}

(c) (1) (8)

This work is licensed under a Creative Commons Attribution-NonCommercial 4.0 International License 


\title{
Frankston Phase Ceramics from the Alcoa \#1 (41AN87) Site, Mound Prairie Creek, Anderson County, Texas
}

\author{
Timothy K. Perttula
}

\section{INTRODUCTION}

In 1990, Amick et al. (1991) investigated a well-preserved Late Caddo Frankston phase midden deposit at the ALCOA \#1 (41AN87) site on Mound Prairie Creek, about $7 \mathrm{~km}$ northeast of Palestine, Texas. During the course of that work, more than 900 Caddo ceramic vessel sherds and a few pipe sherds were recovered, but they were only cursorily described by Amick et al. (1991). That was unfortunate at the time because it appeared then, and is still evident now, that the ALCOA \#1 site was a single component $15^{\text {th }}$ century A.D. Frankston phase setticment, and detailed study of the recovered ceramic assemblage would have provided unique insights into the stylistic and technological character of the ceramic vessels being made and used for culinary purposes by the prehistoric Caddo in this part of the Neches River basin.

With the renewed study of the archaeology of the Frankston phase occasioned by the Texas Department of Transportation-sponsored excavations at the Lang Pasture site (41AN38, Perttula et al. 2007)-and the recovery there of a substantial ceramic sherd assemblage - and the reexamination of sherd and vessel collections from Frankston phase collections at the Texas Archeological Research Laboratory, The University of Texas at Austin, I returned to the detailed study of the ALCOA \# I ceramic asscmblage. The assemblage of ceramic vessel sherds from the Amick et al. (1991) work is sufficiently robust that it is possible to characterize with some precision the use of fine wares, utility wares, and plain wares by the $15^{\text {th }}$ century A.D. Caddo that lived at the site.

\section{SITE INVESTIGATIONS}

The ALCOA \#1 site covers no more than 0.5-1 acres in size, with a ca. $100 \mathrm{~m}^{2}$ trash midden deposit that is $60-70 \mathrm{~cm}$ in thickness. In 1990, Amick et al. (1991:Figure 1) excavated a single $1 \times 1 \mathrm{~m}$ unit
(Unit 1), excavatcd in $10 \mathrm{~cm}$ arbitrary levels, in the heart of the midden deposits. A large quantity of ceramic vessels (to be described below), animal bones $(n=799)$, and charred hickory nutshells were recovered in the midden excavations. Calibrated radiocarbon dates obtained from charred nutshells in level $4(30-40 \mathrm{~cm} \mathrm{bs})$ and level $6(50-60 \mathrm{~cm} \mathrm{bs})$ in Unit 1 were: AD 1380-1514 (2 sigma, 0.75 relative area under probability distribution) and AD 12941437 ( 2 sigma, 1.00 relative area under probability distribution), respectively. Calibrated intercepts of the two radiocarbon age ranges were AD 1426 (level 4) and AD 1407 (level 6), suggesting an occupation that began in the early $15^{\text {th }}$ century A.D.

\section{THE CERAMIC ASSEMBLAGE}

The ceranic assemblage lrom the ALCOA \#1 site includes 913 vessel sherds (Table 1) and seven elbow pipe sherds (Table 2). This is a very high density of more than 1300 vessel sherds and 10 pipe sherds per $\mathrm{m}^{3}$ of midden archaeological deposits, and this density suggests that there is an estimated midden content of ca. 91,000 vessel sherds from hundreds of different vessels and ca. 700 pipe sherds from at least 25-50 different pipes. The highest densities of sherds occur at the top and bottom of the midden deposits (see Table 1), but the densities remain quite high throughout the midden deposits, suggesting a continuous accumulation of broken vessels and vessel fragments during the course of the Frankston phase Caddo occupation.

Of the 913 vessel sherds from the ALCOA \#1 site, 335 are decorated. The plain to decorated sherd ratio in this Unit 1 assemblage is 1.73 .

\section{Methods of Analysis}

Detailed analysis of the ceramic sherds (about a $33 \%$ sample) from the ALCOA \#1 site (Appendix 
Table 1. Provenience of Ceramic Sherds from the ALCOA \#1 (41AN87) Site.

\begin{tabular}{lcccc}
\hline Provenience & Plain wares & Utility wares & Fine wares & N \\
\hline Unit 1, 1v. 1 & 143 & 52 & 9 & 204 \\
Unit 1, lv. 2 & 73 & 43 & 7 & 123 \\
Unit 1, lv. 3 & 68 & 41 & 8 & 117 \\
Unit 1, lv. 4 & 73 & 36 & 10 & 119 \\
Unit 1, lv. 5 & 61 & 38 & 12 & 111 \\
Unit 1, lv. 6 & 136 & 50 & 12 & 198 \\
Unit 1, lv. 7 & 24 & 15 & 2 & 41 \\
\hline Totals & 578 & 275 & 60 & 913 \\
\hline
\end{tabular}

Table 2. Provenience of Pipe Sherds from the ALCOA \#1 Site.

\begin{tabular}{lccc}
\hline Provenience & Pipe bowl sherds & Pipe stem sherds & N \\
\hline Unit 1, lv. 2 & 2 & - & 2 \\
Unit 1, lv. 3 & 3 & - & 3 \\
Unit 1, 1v. 6 & 2 & - & 2 \\
\hline
\end{tabular}

1) is based on differences in temper, type of sherd (i.e., rim, body, or base), rim and lip form (cf. Brown 1996:Figure 2-12), decoration (if present), surface treatment (smoothing, burnishing, or polishing; see Rice 1987), and firing conditions (cf. Teltser 1993). Sherd cross-sections were inspected macroscopically and with a $10 \mathrm{X}$ hand lens to determine the character of the paste and its inclusions. Determining the firing conditions is based on the identification of the firing core in the sherd cross-sections and the identification of oxidation patterns as defined in Teltser (1993:535-536 and Figure 2a-h) and Perttula (2005:Figure 5-30i-1).

More specifically, the following attributes were employed in the analysis of the vessel ceramics: (a) temper, the deliberate and indeterminate materials found in the pastc (Rice 1987:411), including a variety of tempers (grog or crushed sherds, grit or crushed quartz pebbles, and burned mussel shell) and "particulate matters of some size;" (b) although most of the sherds are small and thus from indeterminate vessel forms, where sherds were large enough, vessel form categories include open containers (bowls) and restricted containers, including jars and bottles. Other form attributes include rim profile (direct or vertical, and inverted) and lip profile (rounded, flat, or folded to the exterior). In a few cases, base shape could also be recorded. Observations on ceramic sherd cross-sections permit consideration of oxidation patterns (Teltser 1993:Figure 2), namely the conditions under which a vessel was fired and then cooled after firing. Finally, wall thickness was recorded in millimeters ( $\mathrm{mm}$ ), using a vernier caliper, along the mid-section of the sherd.

With respect to interior and exterior surface treatment on the sherds, the primary methods of finishing the surface of the vessels includes smoothing and burnishing, and polishing. Smoothing creates "a finer and more regular surface... [and] has a matte rather than a lustrous surface" (Rice 1987:138). Burnishing creates an irregular lustrous finish marked by parallel facets left by the burnishing tool (perhaps a smoothed pebble or bone). A polished surface treatment is marked by a uniform and highly lustrous surface finish, done when the vessel is dry, but without "the pronounced parallel facets produced by burnishing leather-hard clay" (Rice 1987:138).

Decorative techniques present in the ALCOA \#1 site ceramic sherd collection include engraving and engraving-punctation in the fine wares, and incising, incising-punctated, punctated, brushing, appliqued, and pinching in the utility wares. 
Engraving was done with a sharp tool when the vessel was either leather-hard or after it was fired, while the other decorative techniques were executed with tools (incising and punctation with wood or bone sticks or dowels and brushing with frayed sticks or grass bundles), with finger impressions (pinching) when the vessel was wet or still plastic, and by adding strips and nodes of clay to the vessel body (appliqued).

The 335 decorated sherds from the site (see Table 1) are readily separated into fine wares $(n=60)$ or utility wares $(n=275)$, following the distinctions discussed by Schambach and Miller (1984) at the Cedar Grove site in the Great Bend area in southwestern Arkansas. These distinctions include apparent differences in temper, surface treatment, vessel forms, and decorative methods. Utility wares generally are jars and simple bowls used for the cooking and storage of foods, have a coarse temper, and lack burnishing, polishing, or slipping on interior and exterior vessel sherd surfaces. Such vessel sherds are decorated with brushing, incising, punctations (tool, cane, or fingernail), and appliqued elements, either by themselves or in combination with one or more of these decorative methods (see Perttula et al. 1995; Schambach and Miller 1984; Suhm and Jelks 1962). Fine wares, on the other hand, consist principally of engraved and slipped vessel sherds from carinated bowls, some simple bowls, and bottles. The fine ware vessel sherds more frequently are smoothed or burnished on the exterior vessel surface, and as will be discussed in more detail below, the fine ware vessels from the ALCOA \#1 site were made, fired, and used in different ways than were the utility ware vessels.

\section{Fine Ware Sherds}

The fine ware sherds from the ALCOA \#1 site include 15 rims and 45 body sherds with either engraved ( $n=57,14$ rims) or engraved-punctated $(n=3,1$ rim) elements; they comprise $17.9 \%$ of all the decorated sherds from the site. More than 27\% of the rims from the site are from fine ware vessels. It is likely that with the exception of bottles, which were engraved on the bottle body, the other engraved sherds were from vessels (i.e., carinated bowls) that were decorated only on the rim panel. About $8 \%$ of the engraved fine ware sherds have had a hematite-rich red clay pigment smeared into the engraved design (see Appendix 1); there are no red-slipped fine ware sherds in the assemblage. All of the engraved sherds appear to be from Poynor Engraved vessels.

The 14 engraved rim sherds include six with a single horizontal engraved line on it, probably either the top or bottom of the rim panels that encircle the engraved carinated bowls. One other has closely-spaced diagonal engraved lines, probably part of a scroll, as is a second rim with horizontal and diagonal lines. A third miscellaneous engraved rim has horizontal, diagonal, and vertical lines that form part of a hatched triangle attached to a larger, but unidentifiable, Poynor Engraved motif. Three rims are from Poynor Engraved, var. Hood carinated bowls (Perttula 2008) in that they have horizontal engraved lines under the lip as well as portions of hour glass-shaped columns that extend from near the rim to the vessel carination (Figure 1d, 1). The remaining two rims with engraved decorations from the ALCOA \#1 site are from Poynor Engraved, var. Lang carinated bowls (see Perttula 2008). These have hatched or cross-hatched central circles (see Figure le, h) with a larger engraved motif (ovals or triangles) on the rim panel.

Eleven body sherds with engraving have portions of hatched elements and motifs commonly found on Poynor Engraved vessels. Among these are six with hatched triangles (see Figure $1 \mathrm{f}-\mathrm{g}$ ) at the comers of larger but unidentifiable motifs, three with curvilinear hatched areas, probably also forming triangular elements attached to a larger motif (see Figure 1a-b), probably oval-shaped areas on a rim panel. Another body sherd-of uncertain orientation-has curvilinear hatched triangles in one area and a set of closely-spaced parallel engraved lines in an adjacent area (see Figure 1i).

The remaining engraved sherds include seven with a single straight line, three with sets of curvilinear lines (see Figure 1j, on a carinated bowl), six with opposed sets of lines, and eight with closelyspaced parallel engraved lines.

There are several engraved bottle sherds $(n=7$, see Appendix 1) in the fine ware assemblage. With two exceptions, these have sets of curvilinear lines on the vessel body, but the overall motif is unidentifiable. The other two have either closely-spaced parallel or horizontal-diagonal engraved lines on the bottle body.

The first of the engraved-punctated sherds is a body sherd from a bottle. The small piece has a straight engraved line adjacent to a zone filled with small etched tool punctates. The two others are from one version of decorated Poynor Engraved, var. Lang 


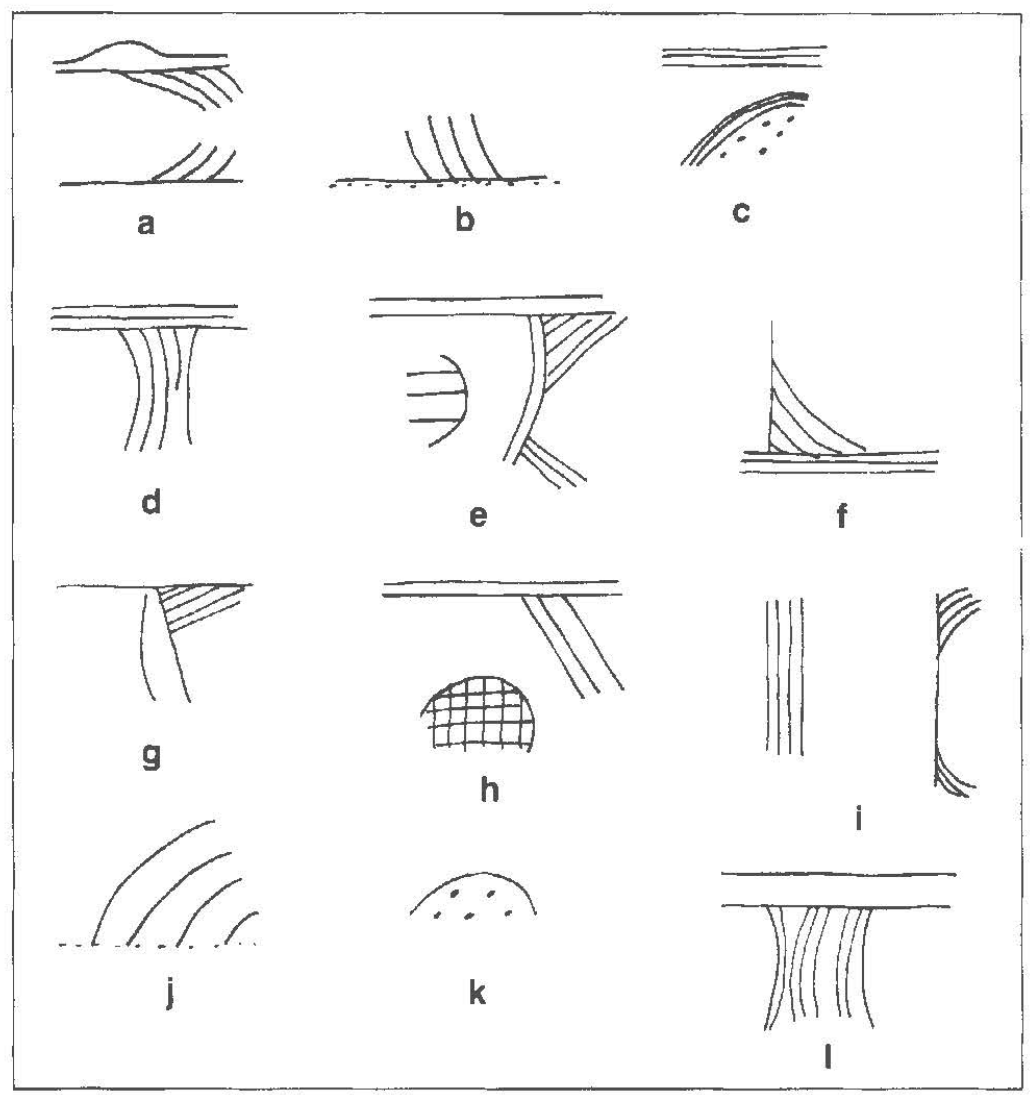

Figure 1. Drawings of selected Poynor Engraved rim and body sherds from the ALCOA \#l site: $a-b, d-j, l$, engraved; $c, k$, engraved-punctated.

carinated bowls (Perttula 2008). Both have small engraved circles filled with etched tool punctations (see Figure 1c, k), and these punctated-filled circles are centered within large ovals repeated on the rim panel.

\section{Utility Ware Sherds}

The utility ware sherds appear to be from the decorated portions of jars, probably used for cooking and/or food storage. These include $26 \mathrm{rim}$ sherds (mainly from vessels decorated with incised or fingernail punctated elements) and 249 body sherds, or $82.1 \%$ of all the decorated sherds from the ALCOA \#1 site. Many of the decorated utility ware sherds have brushing marks (Table 3), particularly on body sherds. Approximately $70 \%$ of the utility ware body sherds have brushing marks on them, but only $15 \%$ of the utility ware rim sherds, indicating that brushed decorations were confined primarily to the bodies of jars. Other important decorated utility wares include sherds from vessels with incised designs (15.6\% of all the sherds and $50 \%$ of the rims), fingernail punctated sherds $(8.7 \%$ of all the utility ware sherds and $19.2 \%$ of the rims), and incised-punctated vessel sherds (3.6\% of all the utility ware sherds and $11.5 \%$ of the rims) (Table 3 ).

The three brushed rims from the ALCOA \# 1 site have either vertical $(n=1)$ or horizontal $(n=2)$ brushing marks on them. Jar vessel bodies have primarily parallel (or vertical) brushing ( $89 \%$ of the brushed body sherds, $\mathrm{n}=150$ ), with overlapping brushing $(9.5 \%, \mathrm{n}=16)$ or opposed brushing $(1.2 \%, \mathrm{n}=2)$ elements decidedly less well represented.

A few other sherds (see Table 3 ) have brushing in combination with other decorative methods. Four have brushed-incised elements, including one rim with vertical brushing-incising, one body with parallel brushed-incised lines, and two other body sherds with parallel brushing marks with overlapping incised lines. One body sherd has a single vertical row of pinching adjacent to a panel filled with diagonal brushing (Figure 2o). Another body sherd has a row of tool punctates above an area with vertical brushing marks; the tool punctated row is probably at the rim-body juncture. The last such body sherd has overlapping brushing marks and a straight incised line, with fingernail punctates pushed through the brushing. 
Table 3. Decorated Utility Ware Sherds.

\begin{tabular}{lccc}
\hline Decorative method & Rim sherd & Body sherd & N \\
\hline Brushed & 3 & 168 & 171 \\
Brushed-incised & 1 & 3 & 4 \\
Brushed-punctated & - & 1 & 1 \\
Brushed-pinched & - & 1 & 1 \\
Brushed-incised-punctated & - & 1 & 1 \\
Fingernail punctated & 5 & 19 & 24 \\
Tool punctated & 1 & 8 & 9 \\
Linear punctated & - & 1 & 1 \\
Pinched-punctated & - & 1 & 1 \\
Incised & 13 & 30 & 43 \\
Incised-punctated & 3 & 7 & 10 \\
Appliqued & - & 5 & 5 \\
Appliqued-punctated & - & 3 & 3 \\
Appliqued-incised & - & 1 & 1 \\
\hline Total & & & 249 \\
\hline
\end{tabular}

Vessel sherds with incised line decorations are an important part of the decorated utility wares at the ALCOA \#1 site. As previously mentioned, more than $15.6 \%$ of all the utility ware sherds are incised, as well as $50 \%$ of all the utility ware rim sherds (see Table 3).

The incised rim sherds are dominated by those that have sets of diagonal incised lines $(n=7$ or $54 \%$ of the incised rims), usually widely-spaced around the rim. Other rims with incised line decorations include one with cross-hatched incised lines, another with horizontal incised lines, one with horizontal and diagonal lines, and a fourth with vertical and diagonal incised lines. Two more distinctive incised rims include: one with large alternating and hatched incised triangles (see Figure $2 b$ ) that extend from the rim to a set of horizontal incised lines farther down the vessel body, and another with large alternating triangles and triangular incised corners where the hatched lines are pitched in different directions (see Figure 2c); this rim also has pinched strap handles that apparently served to divide the incised rim panel.

Incised body sherds have almost exclusively simple straight or geometric designs; one incised body sherd has a series of curvilinear lines. This includes 12 with a single straight incised line, 13 with parallel sets of lines (orientation on the vessel is uncertain), and three with opposed incised lines (see Figure 2d). Of those with parallel incised lines, $85 \%$ have widely-spaced and parallel lines; the others are closely-spaced.

Including one pinched-punctated sherd, $12 \%$ of the utility ware sherds (and $23.1 \%$ of the rim sherds) from the ALCOA \#1 site have punctated decorative elements ( $n=35$ sherds). Most of these are fingernail punctated, either in vertical panels $(n=5)$ on rims (see Figure $2 a)$ or in rows $(n=18)$ on the vessel rim or body. One body sherd has free or randomly placed large fingernail punctates. One tool punctated rim has sets of vertical panels, but the eight body sherds have one or more rows of tool punctations. Another body sherd has rows of closely-spaced linear punctations. Finally, one body sherd has a rectilinear row of pinching that encloses a zone filled with fingernail punctations (see Figure 2n).

Incised-punctated sherds $(n=10)$ comprise $3.6 \%$ of all the utility ware sherds, and $11.5 \%(n=3)$ of the utility ware rim sherds. In eight of the 10 sherds, the decoration consists of either straight, diagonal, or opposed incised line elements that have been employed to create zones filled with tool punctations $(n=7)$ or fingernail punctations $(n=1)$. These incised and punctated-filled zones may be triangular (see Figure $2 \mathrm{~g}$ ) or rectangular panels (see Figure $2 \mathrm{~h}$ ), or sherds with combinations of different-sized triangles (see Figure 2i) on a vessel rim. Two sherds have 


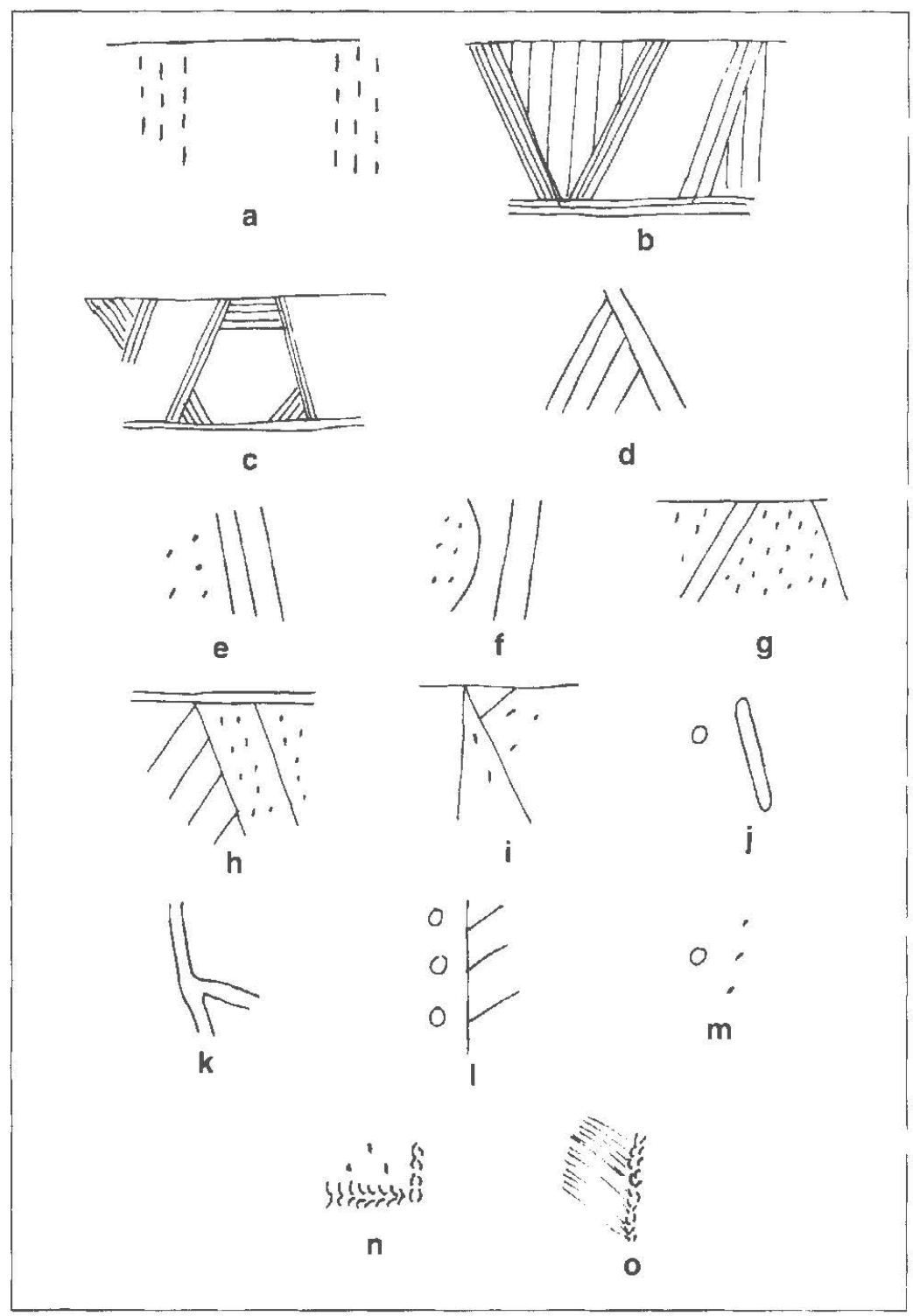

Figure 2. Utility ware decorated sherds from the ALCOA \#1 site: a, fingernail punctated panel; b-d, incised; e-i, incised-punctated; j-k, appliqued; 1 , appliquedincised; $\mathrm{m}$, appliqued-punctated; $n$, pinched-fingernail punctated; o, pincheddiagonal brushed.

circular or curvilinear incised elements, one an incised circle filled with tool punctations (see Figure $2 \mathrm{f}$ ) and the other with sets of curvilinear incised lines and a tool-punctated zone of uncertain form.

Nine body sherds have appliqued decorations (see Table 3 ), $3.3 \%$ of all the utility ware sherds. The most common include appliqued nodes $(\mathrm{n}=1)$, ridges $(n=3$, see Figure $2 k$ ), or ridges and nodes ( $n=1$, Figure $2 \mathrm{j}$ ). One jar handle has three vertical appliqued ridges on it. Three other body sherds have either ridges $(n=2)$ or nodes $(n=1)$ on the vessel body, with fingernail punctated $(n=2)$ or tool punctated $(n=1$, see Figure $2 \mathrm{~m}$ ) rows or zones adjacent to the appliqued elements. Finally, another sherd-possibly part of a jar handle-has a broad appliqued ridge with three appliqued nodes on it; adjacent to the broad appliqued ridge are several diagonal incised lines (see Figure 21).

\section{Plain Ware Sherds}

The 578 plain ware sherds include 14 rims, 554 body sherds, and 10 base sherds. While many of the plain sherds in the ALCOA \#1 assemblage 
are undoubtedly from the undecorated portions of decorated fine ware and utility ware vessels, the proportion of plain rims among all the rims in the assemblage $(25.4 \%)$ and the ratio of plain to decorated rims (1:2.9) indicates that plain vessels (probably bowls, carinated bowls, and an occasional bottle, see Appendix 1) comprise a substantial part of the vessels made and used by the Caddo during the occupation.

\section{Assemblage Characterization of the Vessel Sherds}

In this section, I discuss the character of the ALCOA \# 1 vessel sherd assemblage with respect to the use of different kinds of temper and the apparent use of a naturally sandy clay for vessel manufacture, firing conditions, vessel wall thickness, and rim and lip form. These comparisons provide a good sense of the various technological attributes that characterize prehistoric Caddo pottery manufacture in the upper Neches River basin.

\section{Temper and Paste}

The ALCOA \# 1 ceramic sherds from the plain wares, utility wares, and fine wares are tempered with grog or crushed sherds (Table 4). Between $90.7-93.9 \%$ of the sherds from the site have grog temper, which is consistent with other upper Neches River Frankston and Allen phase sites (Perttula 2007:80 and Table 1).

A notable feature of the ALCOA \#1 sherd assemblage, however, is the regular use of crushed hematite as a temper, particularly in the plain wares and utility wares (54.4-55.4\%), but even abundant in the fine wares $(45.4 \%)$. Crushed and burned bone was a decidedly secondary choice as a temper additive by Caddo potters at the site, comprising only $2.2-11.4 \%$ of the sherds in the three wares. Less than $10 \%$ of the sherds have charred organic materials preserved in the paste, and this material is less a deliberate temper than an accidental organic inclusion in the clay paste that was not completely combusted (probably due to a short firing episode) during firing.

Table 4. Temper.

\begin{tabular}{lccc}
\hline Temper Categnry & Plain ware & Utility ware & Fine ware \\
\hline grog & $34.2 *$ & 40.0 & 43.4 \\
grog-bone & 6.1 & 0.0 & 3.8 \\
grog-hematite & 45.6 & 44.4 & 32.1 \\
grog-hematite-organics & 0.9 & 2.2 & 1.9 \\
grog-organics & 5.3 & 4.4 & 5.7 \\
grog-hematite-bone & 1.8 & 2.2 & 1.9 \\
bone-grog & 0.0 & 0.0 & 1.9 \\
bone-hematite & 3.5 & 1.5 & 1.9 \\
bone-hematite-organics & 0.0 & 0.7 & 0.0 \\
hematite & 2.6 & 4.4 & 5.7 \\
hematite-organics & 0.0 & 0.0 & 1.9 \\
& & & \\
\% grog & 93.9 & 93.2 & 90.7 \\
\% bone & 11.4 & 2.2 & 9.5 \\
\% hematite & 54.4 & 55.4 & 45.4 \\
$\%$ organics & 6.2 & 7.3 & 9.5 \\
\% Sandy paste & & & 11.3 \\
\hline Totals & 8.8 & 23.7 & 53 \\
\hline
\end{tabular}

*percentage 
The addition of coarse fragments of crushed hematite and bone, either separately or together, found in $54.9-65.8 \%$ of the sherds (see Table 4), would have made the clay selected for vessel manufacture more plastic and increased its strength and use-life. These were properties that were important in the successful manufacture of durable pottery vessels, along with the use of grog. The selection of grogsometimes finely crushed-as the primary temper by the Frankston phase potters may have been for both technological and stylistic properties. The addition of grog in the paste would slow the oxidation process, creating darker-colored vessels in reducing environments, while allowing them to be fired longer, with more control, and producing a harder ceramic (Rice 1987:354; Teltser 1993:532, 540). Furthermore, because grog would have comparable expansion coefficients to that of the clay paste, this would contribute to the ability of a fired vessel to withstand heat-related stresses, increase its flexural strength (O'Brien et al. 1994:281; Rice 1987:362), and have better thermal conductivity.

Sherds with a sandy paste account for between $8.8 \%$ and $23.7 \%$ of the ALCOA \#1 sherds (see Table 4). Most of these are among the utility ware sherds $(23.7 \%)$, with lesser but comparable amounts among the plain wares and fine wares $(8.8-11.3 \%)$. It is likely that these differences are apparent becausc Caddo potters recognized that sandy clays held up better to heat-related stresses and helped with vessel porosity and thermal conductivity, all beneficial in vessels designed to receive repeated use for cooking and heating foods and liquids, such as the utility ware cooking jars, while vessels designed for different purposes (i.e., the plain wares and fine wares) have different paste compositions (see Rice 1996:139).

\section{Firing}

The Caddo vessel sherds from the AI.COA \# 1 site were fired under a variety of conditions (Table 5 ), primarily in a reducing or low oxygen environment, probably because of the smothering of the vessel in a bed of coals from a wood fire. This method of firing is typical of Caddo ceramic assemblages throughout East Texas. After firing, most of the vessels were apparently cooled in a high oxygen environment (especially the plain wares and the fine wares), meaning that the fire-hardened vessels were probably removed from the fire to cool, producing a thin oxidizcd or lighter surface on either one (i.e., firing conditions $\mathrm{G}$ and $\mathrm{H}$ ) or both (i.e., firing condi- tion $F$ ) vessel surfaces.

About $69 \%$ of the fine wares were fired in a reducing environment, compared to $48.1-55.7 \%$ in the utility wares and plain wares, respectively (see Table 5). The fine ware vessel sherds are Irom vessels that were better made and better fired (in terms of regulating the firing temperature), as well as probably fired longer in a low oxygen environment. This produced fine ware vessels that were harder and more durable than the other two ceramic wares from the site.

Between $30.8-45.2 \%$ of the vessel sherds are from vessels that werc fired in either a high oxygen environment or they were not completely oxidized during firing; the highest proportion of sherds fired in this manner occur among the utility wares (see Table 5). In the latter case, this probably represents a situation where it was not necessary, provided that their porosity was not excessive, for utility vessels to be fired for as long a time as the harder fine wares, but still remained serviceable over time without being subject to diminished strength from cumulative thermal fatigue as well as cracks and fractures.

There are significant differences in how utility wares and fine ware vessels were fired at the ALCOA \#1 site, with the plain wares intermediate in firing conditions, indicating its more diverse formal and functional character. Nevertheless, the relative consistency in how the vessels at the ALCOA \#1 site were fired indicates that the Caddo potters who made those vessels were well-versed in regulating firing and cooling temperatures as well as maintaining control over the final finished end product, namely the manufacture of durable and relatively hard vessels with different forms and functions.

\section{Vessel Wall Thickness}

The fine ware vessel sherds from the ALCOA $\# 1$ site are thinner than the decorated utility ware or plain ware sherds, particularly along the rim (Table 6). These variations in vessel wall thickness are likely related to functional and technological differences in how these different wares were intended to be used by Caddo potters. The more substantial vessel walls in the utility wares would be well suited to the cooking and heating of foods and liquids and would have contributed to their ability to withstand heat-related stresses. Fine wares were probably intended for use in the serving of foods and liquids. while the plain wares were probably used for both cooking and food serving. 
Table 5. Firing Conditions.

\begin{tabular}{lccc}
\hline Firing Condition & Plain ware & Utility ware & Fine ware \\
\hline A & $21.2^{*}$ & 25.9 & 17.3 \\
B & 11.5 & 11.1 & 13.5 \\
C & 8.8 & 5.2 & 13.5 \\
D & 2.7 & 0.7 & 0.0 \\
E & 8.8 & 13.4 & 0.0 \\
F & 22.1 & 14.8 & 34.6 \\
G & 15.9 & 14.1 & 9.6 \\
H & 6.2 & 8.1 & 11.5 \\
I & 0.0 & 2.2 & 0.0 \\
J & 0.0 & 0.7 & 0.0 \\
K & 2.7 & 3.7 & 0.0 \\
Oxidizing & 21.2 & 25.9 & 17.3 \\
Incompletely Oxidized & 20.3 & 19.3 & 13.5 \\
Reducing & 11.5 & 11.1 & 13.5 \\
Reducing, cooled in the & 44.2 & 37.0 & 55.7 \\
open air & & & 0.0 \\
Possible smudged or refired & 2.7 & 6.6 & 52 \\
\hline Totals & 113 & & \\
*percentage & & & \\
\hline
\end{tabular}

Another factor that would influence vessel body wall thickness would be the sequence in which a vessel was constructed (Krause 2007:35). Vessels constructed from the bottom up, as these Late Caddo Frankston phase vessels likely were, would tend to have thinner walls moving up the vessel body towards the rim, with the lower portion of the vessel-especially the base-usually significantly thicker than the upper portions of the vessel.

\section{Rim and Lip Forms}

The plain ware vessels primarily have direct or vertical rims and rounded lip (Table 7), with an occasional vessel (probably a plain carinated bowl) having a rounded and exterior folded lip. Utility wares, almost all from wide-mouthed jars, have both direct and everted rims, with proportionally more of the latter, with rounded and flat lips.

Rims of the tine ware vessels from the ALCOA \#1 site are almost exclusively direct or vertical in orientation (see Table 7), with the exception of a single inverted rim vessel; inverted rim fine ware vessels are present in both Frankston phase and later Allen phase ceramic assemblages in the upper Neches River basin (cf. Suhm and Jelks 1962). Lips on fine wares are proportionally more common to be either flat (as seen in bottles and some bowl forms) or rounded and exterior folded (as noted on carinated bowls).

Only a few rims were large enough, or had sufficient curvature, to measure their orifice diameter. 
Table 6. Mean Vessel wall thickness.

\begin{tabular}{lccc}
\hline Ware & $\begin{array}{c}\text { Rim } \\
\text { (in mm) }\end{array}$ & $\begin{array}{c}\text { Body } \\
\text { (in mm) }\end{array}$ & $\begin{array}{c}\text { Base } \\
\text { (in mm) }\end{array}$ \\
\hline Plain ware & 7.26 & 7.04 & 10.50 \\
Utility ware & 7.28 & 7.42 & - \\
Fine ware & 6.16 & 6.54 & \\
\hline
\end{tabular}

Table 7. Rim and lip forms in the ceramic assemblage from the ALCOA \#1 site.

\begin{tabular}{lcccc}
\hline \multirow{2}{*}{ Rim and Lip form } & Plain ware & Utility ware & Fine ware & $\mathrm{N}$ \\
\cline { 2 - 5 } Direct rim & 16.1 & 38.7 & 45.2 & 31 \\
Everted rim & 12.5 & 87.5 & & 8 \\
Inverted rim & - & - & 100.0 & 1 \\
& 17.9 & 57.1 & 25.0 & 28 \\
Rounded lip & 20.0 & 40.0 & 40.0 & 10 \\
Rounded, exterior folded lip & 12.5 & 50.0 & 37.5 & 8 \\
Flat lip & - & - & 100.0 & 1 \\
Flat, exterior fulded lip & 17.0 & 51.1 & 31.9 & 47 \\
\hline Total percentage & &
\end{tabular}

*percentage of analyzed rims

The fine wares range from $16-32 \mathrm{~cm}$ in orifice diameter, with a mean of $22.8 \mathrm{~cm}$, indicating that large fine ware vessels were in use at the ALCOA \#1 sitc. Utility ware vessels have a similar range in orifice diameter $(18-30 \mathrm{~cm})$, with a mean orifice diameter of $22.9 \mathrm{~cm}$. None of the plain ware rim sherds could be measured for orifice diameter.

\section{Pipe Sherds}

The seven clay pipe sherds (see Table 2) are from at least five different Late Caddo style elbow pipes with short and rounded stems as well as squat but broad bowls. Orifice diameters on two of the pipes range from $3.0-4.0 \mathrm{~cm}$. One of the elhow pipes has a row of tool punctations below the lip of the bowl, while the other pipe sherds are undecorated.

Bowl rims are direct to inverted in profile. with either rounded $(n=1)$ or flat $(n=2)$ lips. The pipes are tempered with grog $(57 \%)$, bone-hematite $(14 \%)$. bone $(14 \%)$, and grog-bone (I $4 \%)$. The pipes are commonly smoothed or hurnished on their extcrior surfaces, although none of them are slipped. More than $70 \%$ of the pipe sherds are from pipes that have been fired in a reducing environment, but then cooled in the open air. The varying thickness of the pipe bowls (ranging from 1.8-7.4 mm) from the AICCOA \#l site indicate that the elbow pipes were made in at least three sizes, the first with a thin-walled bowl $(1.8 \mathrm{~mm})$, another with a large and thick-walled bowl ( $7.4 \mathrm{~mm})$, and an intermediate but more common group with a mean bowl thickness of $3.84 \pm 0.46 \mathrm{~mm}$.

\section{SLMMARY}

Prehistoric Frankston phase Caddo ceramic vessel sherds and pipe sherds dating to the early $15^{\text {th }}$ century A.D. are abundant at the ALCOA \#1 site in the upper Neches River basin. These remains, comprising the fragments of whole vessels and ceramic pipes used either for the producing, storage, preparing. serving, consuming. and disposal of toods or-in the case of the clay pipes-the consumption of smoking products. Based on the archaeological context of the recovered vessel and pipe sherds, these remains werc discarded at a small habitation site, probably that of 
one or two households, that most likely was not occupied for more than 1-2 gencrations. As such, the ceramic vessel and pipe sherd assemblage from the ALCOA \#1 site provide a glimpsc of this aspect of the material culturc of a small group of Caddo families living along Mound Prairie Creck.

The ceramic vessel sherds from the ALCOA \#1 site fall readily into three distinct wares: plain wares, decorated utility wares, and decorated fine wares. Based on the proportion of rim sherds for each of the wares, utility ware vessels used for cooking/food preparation and storage comprise $47 \%$ of the vessels used at the site, followed by fine wares $(27 \%)$ and plain wares $(25 \%)$; the fine wares and plain wares (including bottles and carinated bowls) were used primarily for food serving and the containment of liquids. When compared, each ware is slightly different in temper and paste composition from the other, although grog and hematite were the principal tempers (much like other upper Neches River Caddo households, at least in the casc of the use of grog temper), firing conditions, rim and lip form, and vesscl wall thickness. These differences appear to be related to the different forms and functions of the three wares made and used at the site.

The Frankston phase utility ware ceramic sherds are from vessels that were most commonly decorated on the rim with (a) diagonal or opposed incised lines (Maydelle Incised, see Suhm and Jclks 1962:Plate 52), (b) rows of tool or fingernail punctates (see Suhm and Jelks 1962:Plate 79a-b). or (c) horizontal or vertical brushing marks (Bullard Brushed, see Suhm and Jelks 1962:Plate 11). These vessels-probably cooking jars for the most part tend to have vertical brushing marks on the vessel bodies, regardless of the rim decorative treatment.

Fine wares from the ALCOA \#1 site, on the other hand, are from bottles and carinated bowls decorated with engraved motifs; a small percentage of these motifs have had a red clay pigment rubbed in the engraved lines. The fine ware sherds are from Poynor Engraved vessels (see Suhm and Jelks 1962:Plates 62 and 63), the principal Frankston phase fine ware type in the upper Neches River basin. These vessels have been well burnished or polished, and the local clays along Mound Prairie Crcek that were used turned a rich chocolate brown color when fired in a reducing environment and then allowed to cool in the open air; Frankston phase vessels made from clays available along the Neches River typically turned a reddish-yellow or reddishbrown hue when fired.
In a few cases, it was possible to identify specific varieties of Poynor Engraved in the Al.COA \#1 site fine wares. This includes examples of Poynor Engraved, var. Hood $(n=3)$ and var. Lang $(n=4)$ rim sherds. Given the $15^{\text {th }}$ century A.D. age of the site, it is possible to speculate that these are early varieties of Poynor Engraved, or at least were distinct stylistic varicties of Poynor Engraved that began to be used in the $15^{\text {th }}$ century A.D. Additional radiocarbon dates from the site may clarify the age of these Poynor Engraved varieties, as will radiocarbon dates and the completion of detailed ceramic stylistic analyses from other Frankston phase Caddo sites in the upper Neches River basin.

All of the pipe shcrds are from elbow pipes. Their frequency at the ALCOA \# 1 site suggests that family or community-wide traditions and rituals involving pipes and the smoking of tobacco and other types of plants were alive and well in this particular Caddo household or households. These traditions and rituals were shared with other Caddo families and households across the upper Neches River basin, based on close stylistic and tcchnological similarities in the form, manufacture, and decoration of the clay clbow pipes.

\section{ACKNOWLEDGMENTS}

I would like to thank Dr. James Bruseth and Maureen Brown of the Archeology Division at the Texas Historical Commission for facilitating the study of the 41 AN87 ceramic sherds.

\section{REFERENCES CITED}

Amick. C., E. Furman, T. K. Perttula. J. E. Bruseth, and B. C. Yates

1991 ALCOA \#1 (41AN87); A Frankston Phase Settlement along Mound Prairie Creek, Anderson County, Texas. Caddoan Archeology Newsletter 2(2): 1 1- 15.

Brown, J. A.

1996 The Spiro Ceremonial Center: The Archaeology of Arkansas Valley Caddoan Culture in Eastern Oklahoma. 2 Vols. Memoirs No. 29. Museum of Anthropology, University of Michigan. Ann Arhor.

Krause, R. A.

2007 A Potter's Tale. In Plains Village Archaeology: Bison-hunting Farmers in the Central and Northern Plains, edited by S. A. Ahler and M. Kay, pp. 32-40. University of Utah Press, Salt Lake City. 


\section{Journal of Northeast Texas Archaenlogy}

O'Brien, M. J., T. D. Holland, R. J. Hourd, and G. L. Fox

1994 Evolutionary Implications of Design and Performance Characteristics of Prehistoric Pottery. Journal of Archaeological Method and Theory 1:259-304.

Perttula, T. K.

2007 One Attempt at Defining Allen Phase Ceramic Subclusters. Journal of Northeast Texas Archaeology 26:77-81.

2008 Trends and Varieties in Late Caddo and Historic Cadkw Fine Ware Pottery Types in the Upper Neches River Basin. Joumal of Northeast Texar Archaenlogy 28:5!-55.

Perttula. 1. K. (editor)

2005 Archeological Investigations at the Pilgrim's Prule' Site (4lC.P304), a Titus Phase Community in the Big Cypress Creek Basin. 2 Vols. Report of Investigations No. 30. Archeological \& Environmental Consultants, LLC, Austin.

Perttula, T. K., D. B. Kelley, D. E. Wilson, and B. M. Albert 2007 Final Research Design for Data Recovery Excavations at 41 AN38, Anderson County, Texas. Coastal Environments. Inc. and Archeological \& Environmental Consultants, LLC, Baton Rouge and Austin.

Perttula, T. K., M. R. Miller, R. A. Ricklis, D. J. Prikryl, and C. Lint7.

1995 Prehistoric and Historic Aboriginal Ceramics in Texas. Bulletin of the Texas Archeological Society 66:175-235.
Rice, P. M.

1987 Pottery Analysis: A Sourcebook. University of Chicago Press, Chicago.

1996 Recent Ceramic Analysis: 1. Function, Style, and Origins. Journal of Archaeological Research 4:133163.

Schambach. F. F. and J. E. Miller

1984 A Description and Analysis of the Ceramics. In Cedar Grove: An Interdisciplinary Investigution of a Late Caddo Farmstead in the Red River Vulley, edited by N. L. Trubowitz, pp. 109-170. Rest. . h Series No. 23. Arkansas Archeological Survey, Fayetteville.

Suhm, D. A. and F. B. Jclks (editors)

1962 Handbook of Texas Archeology: Type Descriptions. Special Publication No. 1, Texas Archeological Society, and Bulletin No. 4, Texas Memorial Museum, Austin.

Teltser, P. A.

1993 An Analytic Strategy for Studying Assemblage-Scale Ceramic Variation: A Case Study from Southeant Missouri. American Antiquity 54, 3):530-543. 


\section{APPENDIX 1, DETAILED ANALYSIS OF DECORATED AND PLAIN SHERDS}

\begin{tabular}{|c|c|c|c|c|c|c|c|}
\hline Provenience & Sherd & Temper & $\mathrm{ST}^{*}$ & $\mathrm{FC}$ & Th & Decoration & Comments \\
\hline \multicolumn{8}{|l|}{ Plain wares } \\
\hline \multirow[t]{22}{*}{ Unit $1,1 \mathrm{v}, 1$} & rim & $\mathrm{g}$ & - & A & 6.6 & - & $-\mathrm{RO}$ \\
\hline & body & $g-h$ & I SM & $\mathrm{B}$ & 6.5 & - & \\
\hline & body & $\mathrm{g}-\mathrm{h}$ & $\mathrm{I} / \mathrm{E} \mathrm{SM}$ & $\mathrm{E}$ & 6.7 & - & \\
\hline & body & $\mathrm{g}$ & E SM & B & 7.6 & - & \\
\hline & body & $g-b$ & I/E SM & A & 7.7 & - & \\
\hline & body & $\mathrm{g}-\mathrm{h}$ & 1/E SM & A & 4.8 & - & \\
\hline & body & $\mathrm{g}$ & I/E SM & $\mathrm{A}$ & 7.3 & - & \\
\hline & body & $g-h$ & E SM & $\mathrm{A}$ & 7.1 & - & \\
\hline & body & $\mathrm{g}-\mathrm{h}$ & EB/ISM & A & 6.0 & - & \\
\hline & body & $g-b$ & I/E SM & $\mathrm{C}$ & 7.1 & - & \\
\hline & body & g-h & $\mathrm{I} / \mathrm{E} \mathrm{SM}$ & $\mathrm{A}$ & 6.7 & - & \\
\hline & body & $g-h$ & I/E SM & $F$ & 7.2 & - & \\
\hline & body & $g-h$ & l/E SM & $\mathrm{A}$ & 6.2 & - & \\
\hline & body & $g-h$ & I/E SM & $\mathrm{A}$ & 7.2 & - & \\
\hline & body & $g-h$ & E B & $\mathrm{B}$ & 8.4 & - & \\
\hline & body & $g-0$ & E B & $\mathrm{F}$ & 5.9 & - & Bottle \\
\hline & body & g-o & I/E SM & $\mathrm{F}$ & 6.3 & - & \\
\hline & body & $\mathrm{g}-\mathrm{h}$ & $\mathrm{I} / \mathrm{E} \mathrm{SM}$ & A & 7.0 & - & \\
\hline & body & $g-h / S P$ & $\mathrm{I} / \mathrm{E} \mathrm{SM}$ & G & 6.2 & - & \\
\hline & body & $g-h$ & E SM & G & 5.5 & - & \\
\hline & body & $\mathrm{g}$ & I/E SM & $\mathrm{A}$ & 7.5 & - & \\
\hline & body & $\mathrm{g}$ & - & A & 7.2 & - & \\
\hline \multirow[t]{14}{*}{ Unit I, lv. 2} & body & $\mathrm{b}-\mathrm{h} / \mathrm{SP}$ & I SM & $\mathrm{C}$ & 7.7 & - & \\
\hline & body & $\mathrm{g}$ & I/E B & $\mathrm{F}$ & 7.1 & - & \\
\hline & body & $\mathrm{g} / \mathrm{SP}$ & I/E SM & $\mathrm{K}$ & 7.3 & - & \\
\hline & body & $\mathrm{g}-\mathrm{h}$ & I/E SM & A & 6.7 & - & \\
\hline & body & $\mathrm{g}$ & E SM & $\mathrm{C}$ & 6.2 & - & \\
\hline & body & $\mathrm{g}$ & E B & - & - & - & \\
\hline & body & $g-h$ & E B & $\mathrm{H}$ & 7.1 & - & \\
\hline & body & $\mathrm{g}$ & I/E SM & $\mathrm{G}$ & 5.1 & - & \\
\hline & body & b-h & I/E SM & $\mathrm{H}$ & 7.1 & - & \\
\hline & body & $\mathrm{g} / \mathrm{SP}$ & I/E SM & $\mathrm{F}$ & 6.2 & - & \\
\hline & body & $\mathrm{h} / \mathrm{SP}$ & L/E SM & $\mathrm{K}$ & 5.3 & - & \\
\hline & body & $\mathrm{g}$ & I/E SM & A & 5.9 & - & \\
\hline & body & $\mathrm{g}$ & I/E SM & B & 8.4 & - & \\
\hline & base & $g-h / S P$ & - & $\mathrm{D}$ & 10.1 & - & \\
\hline \multirow[t]{6}{*}{ Unit 1, lv. 3} & body & $g-h$ & EB/ISM & $\mathrm{E}$ & 6.9 & - & \\
\hline & body & b-g & I/E SM & $\mathrm{E}$ & 7.6 & - & \\
\hline & body & $\mathrm{g}$ & $\mathrm{I} / \mathrm{E} \mathrm{SM}$ & $\mathrm{H}$ & 8.9 & - & \\
\hline & body & $g$ & $\mathrm{I} / \mathrm{E} \mathrm{B}$ & $\mathrm{B}$ & 6.9 & - & \\
\hline & body & $g-h$ & $\mathrm{I} / \mathrm{E} \mathrm{SM}$ & A & 6.0 & - & \\
\hline & body & $\mathrm{g}-\mathrm{h}$ & E SM & $\mathrm{E}$ & 6.8 & - & \\
\hline
\end{tabular}




\begin{tabular}{|c|c|c|c|c|c|c|c|}
\hline Provenience & Sherd & Temper & $\mathrm{ST}^{*}$ & $\mathrm{FC}$ & Th & Decoration & Comments \\
\hline \multirow[t]{8}{*}{ Unit I, Iv: 3} & body & $\mathrm{g}$ & 1/E SM & $\mathrm{F}$ & 7.9 & - & \\
\hline & body & $\mathrm{g}$ & $\mathrm{I} / \mathrm{E} \mathrm{B}$ & B & 8.0 & - & \\
\hline & body & $\mathrm{g}$ & I/E B & B & 5.8 & - & \\
\hline & body & $g-b$ & EB/ISM & $\mathrm{F}$ & 6.5 & - & \\
\hline & body & $g-b$ & I B & $\mathrm{G}$ & 7.8 & - & \\
\hline & body & $g-h$ & ESM/IB & $\mathrm{E}$ & 7.4 & - & \\
\hline & body & $\mathrm{g}$ & EB/ISM & G & 7.1 & - & \\
\hline & body & g-o & I/E SM & $\mathrm{F}$ & 5.9 & - & \\
\hline \multirow[t]{18}{*}{ Unit 1, lv. 4} & rim & $\mathrm{g}$ & - & $\mathrm{B}$ & 7.6 & - & D-RO \\
\hline & rim & $g-b$ & I B & $\mathrm{E}$ & 6.9 & - & D-RO \\
\hline & body & $g-0$ & l/E B & $\mathrm{F}$ & 6.7 & - & Carinated bowl \\
\hline & body & $h$ & I/E SM & $\mathrm{C}$ & 8.4 & & \\
\hline & body & $g-h$ & I/E SM & A & 6.2 & - & \\
\hline & body & $g-h$ & I/E SM & $\mathrm{A}$ & 6.8 & - & \\
\hline & body & $g$ & E B & G & 6.3 & - & \\
\hline & body & $\mathrm{g}$ & 1/E SM & G & 7.7 & - & \\
\hline & body & $g-h$ & E SM & $\mathrm{A}$ & 8.0 & - & \\
\hline & body & $g-h$ & IB/ESM & $\mathrm{C}$ & 6.9 & - & \\
\hline & body & $g-h$ & I/E B & $\mathrm{E}$ & 5.8 & - & \\
\hline & body & $g-h$ & I SM & $\mathrm{F}$ & 8.3 & - & \\
\hline & body & b-h & I/E SM & $\mathrm{F}$ & 8.3 & - & \\
\hline & body & $g-h$ & EB/ISM & A & 7.5 & - & \\
\hline & body & $\mathrm{g}-\mathrm{h}$ & I/E B & B & 9.5 & - & \\
\hline & base & $\mathrm{g}-\mathrm{h} / \mathrm{SP}$ & I SM & A & 10.0 & - & \\
\hline & hase & g & E SM & G & 9.9 & - & \\
\hline & base & g & I SM & B & 11.3 & - & \\
\hline \multirow[t]{14}{*}{ Unit 1, lv. 5} & rim & $g-b$ & - & B & 8.8 & - & \\
\hline & body & g-h-o & I SM & $\mathrm{H}$ & 9.6 & - & \\
\hline & body & g-b-h & E SM & $\mathrm{F}$ & 6.3 & - & \\
\hline & body & $\mathrm{g}-\mathrm{h}$ & EB/ISM & $C$ & 7.5 & - & \\
\hline & body & $g-h$ & I/E B & $\mathrm{G}$ & 5.6 & - & \\
\hline & body & $g-h$ & I/E SM & $\mathrm{D}$ & 6.8 & - & \\
\hline & body & $\mathrm{g}$ & E SM & $\mathrm{H}$ & 8.3 & - & \\
\hline & body & $g-h$ & EB/ISM & $\mathrm{C}$ & 8.9 & - & \\
\hline & body & $g-h$ & & $\mathrm{~B}$ & 6.2 & - & \\
\hline & body & $\mathrm{g}$ & I/E B & G & 5.6 & & \\
\hline & body & $g-h$ & $\mathrm{~EB} / \mathrm{ISM}$ & $\mathrm{C}$ & 8.6 & - & \\
\hline & body & $\mathrm{h}$ & EB/ISM & $\mathrm{A}$ & 7.4 & - & \\
\hline & body & g-b-h & I/E B & $\mathrm{F}$ & 6.2 & - & \\
\hline & body & g-h & I SM & A & 7.4 & & \\
\hline \multirow[t]{4}{*}{ Unit 1, lv. 6} & rim & $\mathrm{g}$ & $I / E B$ & $\mathrm{~F}$ & 7.5 & - & $D \cdot R()$ \\
\hline & rim & $\mathrm{g}$ & & A & 7.1 & - & $-R O$. ext $f$ \\
\hline & hody & $g-0$ & $\mathrm{I} / \mathrm{E} \mathrm{B}$ & $\mathrm{F}$ & 6.0 & & \\
\hline & body & $\mathrm{g}-\mathrm{h}$ & I/E B & $\mathrm{F}$ & 6.3 & & \\
\hline
\end{tabular}




\begin{tabular}{|c|c|c|c|c|c|c|c|}
\hline Provenience & Sherd & Temper & $\mathrm{ST}^{*}$ & $\mathrm{FC}$ & $\mathrm{Th}$ & Decoration & Comments \\
\hline \multirow[t]{21}{*}{ Unit 1, 1v. 6} & body & $\mathrm{g}$ & E B & $\mathrm{F}$ & 6.5 & - & \multirow{7}{*}{ Bottlc } \\
\hline & body & $\mathrm{g} / \mathrm{SP}$ & E B & $\mathrm{F}$ & 6.2 & - & \\
\hline & body & $g-h$ & E B & $\mathrm{F}$ & 6.6 & - & \\
\hline & body & $\mathrm{g}$ & I/E SM & B & 7.4 & - & \\
\hline & body & g-h & I/E SM & $\mathrm{F}$ & 7.9 & - & \\
\hline & body & $\mathrm{g}-\mathrm{h} / \mathrm{SP}$ & I/E SM & $\mathrm{F}$ & 8.6 & - & \\
\hline & body & $g-h$ & EB/ISM & $\mathrm{F}$ & 7.5 & - & \\
\hline & body & $\mathrm{g}$ & I SM & G & 8.4 & - & \multirow{7}{*}{$\begin{array}{l}\text { pinkware } \\
\text { Bottle }\end{array}$} \\
\hline & body & $\mathrm{g}$ & E B & $\mathrm{G}$ & 5.4 & - & \\
\hline & body & $\mathrm{g}-\mathrm{h}$ & I/E SM & A & 8.0 & - & \\
\hline & body & $\mathrm{b}-\mathrm{h} / \mathrm{SP}$ & E SM & $\mathrm{G}$ & 8.4 & - & \\
\hline & body & g-h & $1 / E B$ & G & 7.1 & - & \\
\hline & body & $\mathrm{g}-\mathrm{h}$ & E B & $\mathrm{C}$ & 6.7 & - & \\
\hline & body & $g-h$ & I/E SM & $\mathrm{F}$ & 6.7 & - & \\
\hline & body & $\mathrm{g}$ & EB/ISM & $\mathrm{G}$ & 6.5 & - & \multirow{7}{*}{ Bottle } \\
\hline & body & $\mathrm{g}$ & E B & $G$ & 6.5 & - & \\
\hline & body & g-o & E B & $\mathrm{H}$ & 7.0 & - & \\
\hline & body & g-h & E B & $\mathrm{F}$ & 5.9 & - & \\
\hline & body & $\mathrm{g}$ & I SM & $\mathrm{E}$ & 6.7 & - & \\
\hline & base & $\mathrm{g}-\mathrm{h}$ & E SM & $E$ & 12.0 & - & \\
\hline & base & g-h & I SM & $\mathrm{D}$ & 9.7 & - & \\
\hline \multirow[t]{5}{*}{ Unit 1, lv. 7} & $\mathrm{rim}$ & g-h & $\mathrm{I} / \mathrm{E} \mathrm{B}$ & G & 7.1 & - & \multirow[t]{5}{*}{$D-R O, e x t f$} \\
\hline & body & $g-h$ & I/E SM & $\mathrm{E}$ & 8.9 & - & \\
\hline & body & g-h & $\mathrm{IB} / \mathrm{ESM}$ & G & 8.6 & - & \\
\hline & body & $\mathrm{g}$ & I/E SM & $\mathrm{F}$ & 8.5 & - & \\
\hline & body & $\mathrm{g}$ & $\mathrm{I} / \mathrm{E} B$ & $\mathrm{~K}$ & 5.7 & - & \\
\hline
\end{tabular}

\begin{tabular}{lllllll}
\hline Provenience Sherd Temper & ST & FC & Th & Decoration & Comments
\end{tabular}

\section{Utility wares}

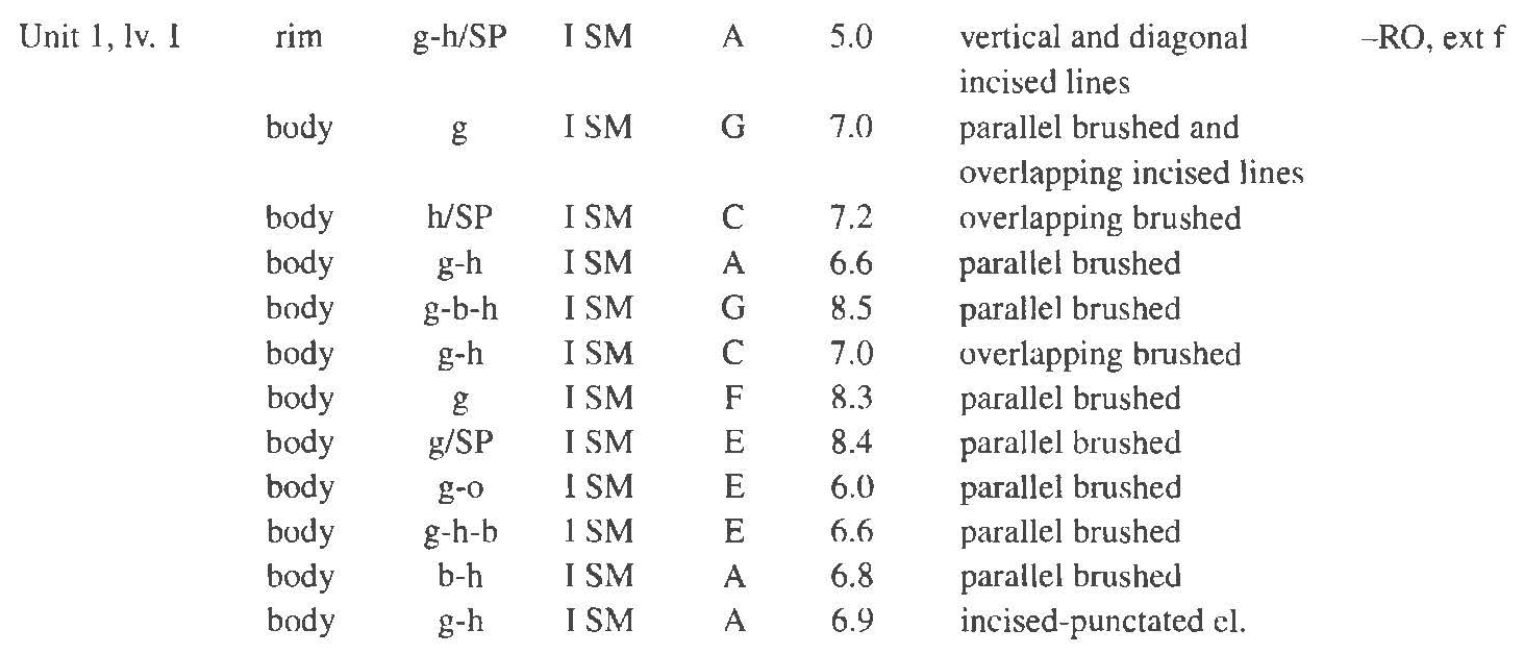




\begin{tabular}{|c|c|c|c|c|c|c|c|}
\hline Provenience & Sherd & Temper & $\mathrm{ST}^{*}$ & $\mathrm{FC}$ & Th & Decoration & Comments \\
\hline & body & $\mathrm{g}-\mathrm{h}$ & I SM & $\mathrm{F}$ & 7.3 & & \\
\hline & & & & & & line and tool punctated & \\
\hline & rim & $\mathrm{g}$ & I SM & G & 6.5 & $\begin{array}{l}\text { filled zone } \\
\text { vertical fingernail } \\
\text { punctated }\end{array}$ & $-\mathrm{RO}$ \\
\hline & body & $\mathrm{g} / \mathrm{SP}$ & I SM & G & 7.5 & fingernail punctated rows & \\
\hline & body & g-h & I SM & A & 6.5 & tool punctated rows & \\
\hline & body & $\mathrm{g}-\mathrm{h} / \mathrm{SP}$ & I SM & $\mathrm{K}$ & 7.5 & appliqued node and ridge & \\
\hline \multirow[t]{10}{*}{ Unit 1, lv. 2} & body & $g$ & - & $\mathrm{B}$ & 5.1 & appliqued node & \\
\hline & body & $\mathrm{g}$ & I SM & $\mathrm{H}$ & 10.3 & parallel brushed & \\
\hline & body & g-h & I SM & $\mathrm{C}$ & 6.5 & overlapping brushed & \\
\hline & body & $g-h$ & I B & $F$ & 7.6 & overlapping brushed & \\
\hline & body & $\mathrm{g}$ & I SM & $\mathrm{G}$ & 8.4 & parallel brushed & \\
\hline & body & $\mathrm{g} / \mathrm{SP}$ & I SM & $E$ & 8.4 & parallel brushed & \\
\hline & body & $\mathrm{g}-\mathrm{h}$ & I SM & $\mathrm{F}$ & 7.9 & parallel brushed & \\
\hline & body & $\mathrm{g}$ & I SM & $\mathrm{E}$ & 8.3 & overlapping brushed & $\begin{array}{l}\text { int. organic } \\
\text { residue }\end{array}$ \\
\hline & body & $g-h$ & I SM & $\mathrm{H}$ & 9.8 & overlapping brushed & \\
\hline & body & $g$ & I B & K & 7.8 & parallel brushed & \\
\hline \multirow[t]{8}{*}{ Unit 1, 1v. 2} & rim & g & I SM & $\mathrm{F}$ & 7.2 & $\begin{array}{l}\text { diagonal incised lines, } \\
\text { closely-spaced }\end{array}$ & D-FL \\
\hline & $\operatorname{rim}$ & $\mathrm{g}$ & I B & $\mathrm{E}$ & 8.2 & Incised el. & $\begin{array}{l}\text { EV-RO. } 23 \\
\mathrm{~cm} \mathrm{OD}\end{array}$ \\
\hline & body & $\mathrm{g}$ & I SM & $\mathrm{E}$ & 6.5 & single straight incised line & \\
\hline & body & $\mathrm{g}$ & I SM & A & 6.0 & single straight incised line & \\
\hline & body & $g-h$ & I SM & A & 7.3 & $\begin{array}{l}\text { parallel incised lines, } \\
\text { widely-spaced }\end{array}$ & \\
\hline & body & $g$ & I SM & C & 6.0 & incised-punctated el. & \\
\hline & body & $\mathrm{g}$ & I SM & $\mathrm{G}$ & 7.6 & tool punctated row & \\
\hline & body & $g-b-h$ & E SM & G & 7.7 & fingernail punctated row & \\
\hline \multirow[t]{11}{*}{ Init 1, lv. 3} & body & $\mathrm{g}$ & $\mathrm{I} / \mathrm{E} \mathrm{B}$ & $(i$ & 8.2 & $\begin{array}{l}\text { pinched-fingernail } \\
\text { punctated }\end{array}$ & \\
\hline & body & $\mathrm{h}$ & - & A & 6.5 & $4+$ linear punctated rows & \\
\hline & rim & $\mathrm{g}-\mathrm{h}$ & I SM & $\mathrm{J}$ & 7.7 & $\begin{array}{l}\text { vertical tool punctated } \\
\text { rows }\end{array}$ & D-RO \\
\hline & body & g-h & I SM & $\mathrm{F}$ & 7.2 & tool punctated rows & \\
\hline & body & $\mathrm{g}-\mathrm{h} / \mathrm{SP}$ & I SM & $F$ & 8.8 & fingernail punctated rows & \\
\hline & body & $\mathrm{g}-\mathrm{h}$ & I SM & A & 5.4 & linear fingernail punctated & \\
\hline & & & & & & rows & \\
\hline & body & $g-0$ & I SM & G & 7.3 & $3+$ linear punctated rows & \\
\hline & rim & g-o & I SM & $\mathrm{B}$ & 7.0 & $\begin{array}{l}\text { incised rim and pinched } \\
\text { strap handle }\end{array}$ & $\begin{array}{l}\text { EV-RO, } 24 \\
\mathrm{~cm} \text { OD }\end{array}$ \\
\hline & rim & $\mathrm{g}$ & I SM & $\mathrm{G}$ & 5.8 & incised-punctated el. & EV-RO, ext I \\
\hline & rim & $g-h$ & - & $\mathrm{B}$ & 8.9 & diagonal incised lines & EV-FL \\
\hline
\end{tabular}




\begin{tabular}{|c|c|c|c|c|c|c|c|}
\hline Provenience & Sherd & Temper & $\mathrm{ST}^{*}$ & $\mathrm{FC}$ & Th & Decoration & Comments \\
\hline & body & g & I SM & $\mathrm{F}$ & 8.6 & $2+$ curvilinear incised lines & \\
\hline & body & g-h & I SM & $\mathrm{E}$ & 7.2 & opposed incised lines & \\
\hline & body & $\mathrm{g}-\mathrm{h} / \mathrm{SP}$ & I SM & A & 7.7 & $\begin{array}{l}\text { parallel incised lines, } \\
\text { widely-spaced }\end{array}$ & \\
\hline & $\operatorname{rim}$ & $\mathrm{h}$ & I SM & A & 6.8 & vertical brushed & EV-RO \\
\hline & body & $\mathrm{g}$ & I SM & $\mathrm{F}$ & 7.3 & parallel brushed & \\
\hline & body & $\mathrm{g}$ & I SM & $\mathrm{E}$ & 8.1 & parallel brushed & \\
\hline & body & $\mathrm{g} / \mathrm{SP}$ & I SM & $\mathrm{B}$ & 6.5 & parallel brushed & \\
\hline & body & $\mathrm{g}-\mathrm{h} / \mathrm{SP}$ & I SM & $\mathrm{C}$ & 7.5 & parallel brushed & \\
\hline & body & $\mathrm{g}-\mathrm{h}$ & I SM & I & 7.4 & parallel brushed & \\
\hline & body & $\mathrm{g}-\mathrm{h} / \mathrm{SP}$ & I SM & $\mathrm{E}$ & 8.4 & ovcrlapping brushcd & \\
\hline & body & g & - & $\mathrm{F}$ & 6.5 & overlapping brushed & \\
\hline & body & $\mathrm{g}$ & I SM & A & 6.5 & $\begin{array}{l}\text { tool punctated row above } \\
\text { vertical brushing }\end{array}$ & \\
\hline \multirow[t]{8}{*}{ Unit 1, lv. 4} & body & $\mathrm{g}-\mathrm{h}$ & I SM & $\mathrm{F}$ & 6.3 & $\begin{array}{l}\text { incised-fingernail } \\
\text { punctated el. }\end{array}$ & \\
\hline & body & $\mathrm{h}$ & $\mathrm{I} / \mathrm{E} \mathrm{SM}$ & A & 6.3 & fingernail punctated row & \\
\hline & body & g-h & I SM & $\mathrm{B}$ & 7.7 & large fingernail punctate & \\
\hline & body & $\mathrm{g}-\mathrm{h} / \mathrm{SP}$ & I SM & $\mathrm{F}$ & 7.3 & $\begin{array}{l}\text { large fingernail punctates } \\
\text { in rows }\end{array}$ & \\
\hline & rim & $g-h$ & I B & $\mathrm{B}$ & 6.6 & cross-hatched incised & D-FL \\
\hline & rim & $\mathrm{g}$ & I SM & $\mathrm{B}$ & 6.2 & diagonal incised line & D-RO \\
\hline & body & $g-h$ & I B & I & 8.0 & single straight incised line & \\
\hline & body & b-h & I SM & A & 5.9 & incised el. & \\
\hline \multirow[t]{7}{*}{ Unit 1, Iv. 4} & body & $g-h$ & I SM & $\mathrm{E}$ & 7.1 & $\begin{array}{l}\text { parallel incised, widely- } \\
\text { spaced }\end{array}$ & \\
\hline & body & $\mathrm{g}$ & I SM & $\mathrm{G}$ & 6.3 & $\begin{array}{l}\text { parallel incised, widely- } \\
\text { spaced }\end{array}$ & \\
\hline & body & $g-h$ & I B & $\mathrm{E}$ & 7.3 & parallel brushed & \\
\hline & body & $\mathrm{g}$ & I B & I & 7.2 & parallel brushed & \\
\hline & body & $g-h$ & I SM & $\mathrm{H}$ & 7.3 & parallel brushed & \\
\hline & body & $g-h$ & I SM & $\mathrm{C}$ & 7.6 & parallel brushed & \\
\hline & body & $g-h$ & I SM & $\mathrm{G}$ & 9.9 & $\begin{array}{l}\text { overlapping brushed- } \\
\text { straight incised line- } \\
\text { fingernail punctates } \\
\text { through brushing }\end{array}$ & \\
\hline \multirow[t]{7}{*}{ Unit 1, lv. 5} & body & g-h & I SM & $\mathrm{B}$ & 7.9 & parallel brushed & \\
\hline & body & g & I SM & $\mathrm{G}$ & 6.8 & parallel brushed & \\
\hline & body & $g-h-o$ & I SM & $\mathrm{F}$ & 7.0 & parallel brushed & \\
\hline & body & g-h-o & - & $\mathrm{F}$ & 8.8 & opposed brushed & \\
\hline & body & $\mathrm{g} / \mathrm{SP}$ & I B & A & 8.0 & overlapping brushed & \\
\hline & body & $g-h$ & - & $\mathrm{E}$ & 7.4 & overlapping brushed & \\
\hline & rim & $g-h$ & I SM & A & 7.8 & vertical brushed-incised & $\begin{array}{l}\text { D-RO, } 18 \\
\mathrm{~cm} \mathrm{OD}\end{array}$ \\
\hline
\end{tabular}


Provenience Sherd Temper ST* FC Th Decoration Comments

\begin{tabular}{|c|c|c|c|c|c|c|c|}
\hline \multirow[t]{20}{*}{ Unit 1, 1v. 5} & rim & $\mathrm{g}-\mathrm{h}$ & I SM & A & 7.3 & horizontal brushed & $\begin{array}{l}\mathrm{D}-\mathrm{RO}, 14+ \\
\operatorname{cm} \mathrm{OD}\end{array}$ \\
\hline & rim & $\mathrm{g}-\mathrm{h}$ & - & $\mathrm{D}$ & 5.3 & $\begin{array}{l}\text { single horizontal incised } \\
\text { line }\end{array}$ & $-\mathrm{RO}$ \\
\hline & $\mathrm{rim}$ & $\mathrm{g}$ & I SM & $\mathrm{K}$ & 6.7 & diagonal incised lines & D-FL \\
\hline & rim & $\mathrm{g}-\mathrm{h}$ & I SM & $\mathrm{G}$ & 7.5 & $\begin{array}{l}\text { horizontal and diagonal } \\
\text { incised lines }\end{array}$ & $\mathrm{D}-\mathrm{RO}$ \\
\hline & rim & $g-h$ & I SM & B & 8.2 & diagonal incised lines & $\begin{array}{l}\text { EV-RO, } 21 \\
\mathrm{~cm} \mathrm{OD}\end{array}$ \\
\hline & body & $g-h / S P$ & I SM & A & 8.2 & $\begin{array}{l}\text { parallel incised lines, } \\
\text { widely-spaced }\end{array}$ & \\
\hline & body & g & I SM & $\mathrm{H}$ & 8.6 & $\begin{array}{l}\text { parallel incised lines, } \\
\text { widely-spaced }\end{array}$ & \\
\hline & body & $g-h$ & E SM & A & 8.2 & $\begin{array}{l}\text { straight incised line and } \\
\text { single tool punctated row }\end{array}$ & \\
\hline & rim & $\mathrm{g}$ & I B & G & 5.0 & incised-punctated el. & $\begin{array}{l}\text { D-RO, ext f, } \\
10+\mathrm{cm} O D\end{array}$ \\
\hline & hody & $\mathrm{g}$ & I SM & $\mathrm{H}$ & 8.6 & $\begin{array}{l}\text { straight incised line and } \\
\text { row of tool punctates }\end{array}$ & \\
\hline & body & $\mathrm{g}$ & I SM & $\mathrm{H}$ & 8.1 & fingernail punctated row & \\
\hline & body & $\mathrm{g} / \mathrm{SP}$ & - & $\mathrm{E}$ & 6.0 & fingernail punctated rows & \\
\hline & body & $\mathrm{g}-\mathrm{h} / \mathrm{SP}$ & - & A & 8.9 & $2+$ tool punctated rows & \\
\hline & body & g & I SM & A & 7.0 & $2+$ fingernail punctated rows & \\
\hline & body & $\mathrm{g}-\mathrm{O}$ & I SM & $\mathrm{H}$ & 9.9 & $\begin{array}{l}\text { widely spaced tool } \\
\text { punctated rows }\end{array}$ & \\
\hline & hody & $\mathrm{g}-\mathrm{h}$ & E SM & A & 6.7 & straight appliqued ridge & \\
\hline & body & h-g & I SM & $E$ & 5.2 & appliqued el. & \\
\hline & body & $g-h$ & I SM & A & 6.5 & $\begin{array}{l}\text { fingernail punctated } \\
\text { rows adjacent to } \\
\text { appliqued ridge }\end{array}$ & \\
\hline & body & $\mathrm{g} / \mathrm{SP}$ & I SM & $\mathrm{H}$ & 8.4 & $\begin{array}{l}\text { fingernail punctated } \\
\text { rows adjacent to } 2+ \\
\text { appliqued nodes }\end{array}$ & \\
\hline & body & $\mathrm{g}-\mathrm{h} / \mathrm{SP}$ & I SM & A & 8.0 & $\begin{array}{l}\text { diagonal incised with } \\
\text { bruad appliqued ridge } \\
\text { with } 3+\text { appliqued nodes }\end{array}$ & \\
\hline \multirow[t]{8}{*}{ Unit 1, ly. 6} & rim & $g-h$ & I SM & $\mathrm{F}$ & 9.6 & horizontal brusbed & $\begin{array}{l}\mathrm{D}-\mathrm{RO}, 2 \mathrm{l}+ \\
\mathrm{cm} \mathrm{OD}\end{array}$ \\
\hline & body & $\mathrm{g} / \mathrm{SP}$ & - & $\mathrm{G}$ & 7.0 & parallel brushed & \\
\hline & body & $\mathrm{g}-\mathrm{h} / \mathrm{SP}$ & I SM & $\mathrm{F}$ & 9.2 & parallel brushed & \\
\hline & body & $\mathrm{h}$ & l SM & A & 6.7 & parallel brushed & \\
\hline & body & $\mathrm{g}$ & - & $\mathrm{E}$ & 6.5 & parallel brushed & \\
\hline & body & $\mathrm{g}-\mathrm{h}$ & l SM & A & 8.1 & paraltel brushed & \\
\hline & body & $\mathrm{g}-\mathrm{h} / \mathrm{SP}$ & I SM & $\mathrm{H}$ & 7.2 & parallel brushed & \\
\hline & body & $\mathrm{g} / \mathrm{SP}$ & - & A & 8.8 & parallel brushed & \\
\hline \multirow[t]{2}{*}{ Unit 1, lv. 6} & body & $g-h$ & l SM & A & 7.6 & overlapping brushed & \\
\hline & bondy & $g-h$ & I SM & $\mathrm{E}$ & 8.9 & overlapping brushed & \\
\hline
\end{tabular}


Provenience Sherd Temper ST* FC Th Decoration Comments

\begin{tabular}{|c|c|c|c|c|c|c|c|}
\hline \multirow[t]{14}{*}{ Unit 1.1v. 6} & body & $\mathrm{g}-\mathrm{h}$ & I B & A & 6.4 & \multicolumn{2}{|l|}{$\begin{array}{l}\text { parallel brushed over- } \\
\text { lapping straight incised line }\end{array}$} \\
\hline & body & $\mathrm{g} / \mathrm{SP}$ & I SM & G & 8.9 & \multicolumn{2}{|l|}{ parallel brushed-incised } \\
\hline & body & $\mathrm{g}$ & I B & B & 3.9 & \multicolumn{2}{|l|}{ pinched-diagonal brushed } \\
\hline & rim & $\mathrm{g} / \mathrm{SP}$ & I SM & G & 5.6 & $\begin{array}{l}\text { diagonal incised lines, } \\
\text { widely-spaced }\end{array}$ & $\begin{array}{l}\text { D-RO, 14+ } \\
\text { cm OD }\end{array}$ \\
\hline & rim & g-h & I SM & A & 7.3 & $\begin{array}{l}\text { single diagonal incised } \\
\text { line }\end{array}$ & $\begin{array}{l}\text { EV-RO, } 30 \\
\mathrm{~cm} \mathrm{OD}\end{array}$ \\
\hline & body & h-b-o/SP & I SM & $\mathrm{H}$ & 7.0 & \multicolumn{2}{|l|}{ diagonal incised line } \\
\hline & body & $\mathrm{g}-\mathrm{O}$ & I SM & $\mathrm{F}$ & 8.1 & \multicolumn{2}{|l|}{$\begin{array}{l}\text { opposed incised lines, } \\
\text { broad lines }\end{array}$} \\
\hline & rim & $\mathrm{g} / \mathrm{SP}$ & I SM & B & 6.6 & \\
\hline & body & $\mathrm{g}$ & I SM & $\mathrm{B}$ & 5.3 & \multicolumn{2}{|l|}{$\begin{array}{l}\text { curvilinear incised- } \\
\text { punctated el. }\end{array}$} \\
\hline & rim & $\mathrm{g}-\mathrm{h}$ & I SM & $\mathrm{H}$ & 8.9 & $\begin{array}{l}\text { fingernail punctated } \\
\text { panels }\end{array}$ & $\begin{array}{l}\text { EV-RO, } 22 \\
\mathrm{~cm} \text { OD }\end{array}$ \\
\hline & body & $\mathrm{g} / \mathrm{SP}$ & - & $\mathrm{F}$ & 6.6 & \multicolumn{2}{|l|}{ tool punctated rows } \\
\hline & body & $\mathrm{g}$ & I B & $\mathrm{B}$ & 8.0 & \multicolumn{2}{|l|}{ fingernail punctated rows } \\
\hline & handle & $\mathrm{g}-\mathrm{h} / \mathrm{SP}$ & - & A & 12.2 & \multicolumn{2}{|l|}{3 vertical appliqued ridges } \\
\hline & body & $g-0$ & I B & B & 4.2 & \multicolumn{2}{|l|}{$\begin{array}{l}\text { appliqued node and } \\
\text { tool punctated row }\end{array}$} \\
\hline \multirow[t]{13}{*}{ Unit 1, Iv. 7} & body & $\mathrm{g}$ & I SM & A & 6.5 & \multicolumn{2}{|l|}{ parallel brushed } \\
\hline & body & $\mathrm{g} / \mathrm{SP}$ & I SM & $\mathrm{K}$ & 6.6 & \multicolumn{2}{|l|}{ parallel brushed } \\
\hline & body & $\mathrm{g}$ & I B & G & 7.7 & \multicolumn{2}{|l|}{ overlapping brushed } \\
\hline & body & g-h & I SM & $\mathrm{C}$ & 6.6 & \multicolumn{2}{|l|}{ parallel brushed } \\
\hline & body & $\mathrm{g}-\mathrm{h} / \mathrm{SP}$ & I SM & A & 7.2 & \multicolumn{2}{|l|}{ parallel brushed } \\
\hline & body & $g-h$ & I SM & A & 8.7 & \multicolumn{2}{|l|}{ overlapping brushed } \\
\hline & body & $\mathrm{g}$ & I SM & $\mathrm{K}$ & 8.2 & \multicolumn{2}{|l|}{ overlapping brushed } \\
\hline & $\operatorname{rim}(3)$ & g-h-o & I SM & $\mathrm{E}$ & 8.5 & $\begin{array}{l}\text { fingernail punctated } \\
\text { panels }\end{array}$ & $\begin{array}{l}\text { EV-RO, ext } f, \\
22 \mathrm{~cm} \text { OD }\end{array}$ \\
\hline & body & g-h-o & I SM & $\mathrm{E}$ & 9.1 & \multicolumn{2}{|l|}{$\begin{array}{l}\text { fingernail punctated } \\
\text { panels }\end{array}$} \\
\hline & body & $\mathrm{g}$ & E SM & $\mathrm{F}$ & 6.2 & \multicolumn{2}{|l|}{$3+$ fingernail punctated rows } \\
\hline & body & $\mathrm{g}-\mathrm{h}$ & I SM & $\mathrm{F}$ & 8.9 & \multicolumn{2}{|l|}{ parallel broad incised lines } \\
\hline & body & $\mathrm{g} / \mathrm{SP}$ & - & A & 8.4 & \multicolumn{2}{|l|}{ single straight incised line } \\
\hline & body & $\mathrm{h}$ & I SM & $\mathrm{B}$ & 7.4 & \multicolumn{2}{|l|}{$\begin{array}{l}7+\text { straight incised lines, } \\
\text { closely-spaced }\end{array}$} \\
\hline
\end{tabular}

Fine wares

$\begin{array}{cccccclc}\text { Unit 1, lv. 1 } & \text { rim } & \text { g } & \text { E B } & \text { B } & 6.0 & \begin{array}{l}\text { Poynor Engraved, var. } \\ \text { Hood }\end{array} & \text { D-RO, ext f } \\ & \text { rim } & \text { g } & \text { E SM } & \text { C } & 4.4 & \begin{array}{l}\text { single horizontal } \\ \text { engraved line } \\ \text { horizontal, vertical, } \\ \text { and diagonal engraved } \\ \text { lines }\end{array} & \text { D-RO }\end{array}$




\begin{tabular}{|c|c|c|c|c|c|c|c|}
\hline Provenience & Sherd & Temper & ST* & $\mathrm{FC}$ & Th & Decoration & Comments \\
\hline & body & $\mathrm{b}-\mathrm{g}$ & $\mathrm{I} / \mathrm{E} \mathrm{SM}$ & $\mathrm{F}$ & 8.4 & $\begin{array}{l}3+\text { curvilinear engraved } \\
\text { lines }\end{array}$ & \\
\hline & body & $\mathrm{g}-\mathrm{h}$ & - & A & 6.3 & $\begin{array}{l}\text { single straight engraved } \\
\text { line }\end{array}$ & Bottle \\
\hline & body & $\mathrm{g}$ & I/E SM & $\mathrm{H}$ & 6.2 & opposed engraved lines & \\
\hline & body & $g$ & E SM & $\mathrm{F}$ & 7.4 & $\begin{array}{l}\text { hatched engraved } \\
\text { triangle }\end{array}$ & red pigment \\
\hline & body & $\mathrm{h}$ & E B & A & 5.9 & $\begin{array}{l}\text { horizontal and vertical } \\
\text { engraved lines }\end{array}$ & Bottle \\
\hline & body & $g-h$ & $\mathrm{I} / \mathrm{E} \mathrm{B}$ & B & 5.4 & opposed engraved lines & \\
\hline \multirow[t]{7}{*}{ Unit 1, 1v. 2} & rim & $\mathrm{g}$ & I/E SM & A & 5.2 & Poynor Engraved el. & $\begin{array}{l}\text { D-RO, rim } \\
\text { peaks }\end{array}$ \\
\hline & body & $g-h$ & E B & G & 5.4 & $\begin{array}{l}3+\text { curvilinear engraved } \\
\text { lines, closely-spaced }\end{array}$ & Bottle \\
\hline & body & $\mathrm{g} / \mathrm{SP}$ & I/E SM & $\mathrm{F}$ & 4.9 & engraved el. & red pigment \\
\hline & body & $g-h$ & $\mathrm{I} / \mathrm{E} \mathrm{SM}$ & A & 4.0 & $\begin{array}{l}\text { 2+ parallel engraved lines, } \\
\text { closely-spaced }\end{array}$ & \\
\hline & body & $\mathrm{g}$ & I/E SM & $\mathrm{H}$ & 7.0 & single straight engraved line & \\
\hline & body & g-h & $\mathrm{EB} / \mathrm{SSM}$ & $\mathrm{F}$ & 6.3 & Poynor Engraved el. & Carinated bowl \\
\hline & body & $\mathrm{g}-\mathrm{h}$ & E B & A & 4.3 & engraved-punctated el. & Bottle \\
\hline \multirow[t]{7}{*}{ Unit 1, 1v. 3} & rim & $g-h-o$ & $\mathrm{I} / \mathrm{E} \mathrm{B}$ & $\mathrm{F}$ & 6.8 & Poynor Engraved el. & $\begin{array}{l}\text { D-RO, ext } \mathrm{f}, \\
32 \mathrm{~cm} \text { OD, } \\
\text { Carinated bowl }\end{array}$ \\
\hline & rim & $g$ & I/E B & $\mathrm{F}$ & 5.0 & Poynor Engraved el. & \\
\hline & body & g-h & E SM & $\mathrm{C}$ & 6.0 & $\begin{array}{l}\text { closely-spaced opposed } \\
\text { engraved lines, Poynor } \\
\text { Engraved }\end{array}$ & Bottle \\
\hline & body & g-h & I/E B & $\mathrm{F}$ & 8.4 & $\begin{array}{l}\text { opposed engraved lines, } \\
\text { Poynor Engraved }\end{array}$ & \\
\hline & body & $g-h$ & EB/ISM & $\mathrm{F}$ & 6.6 & $\begin{array}{l}\text { opposed engraved lines, } \\
\text { Poynor Engraved el. }\end{array}$ & Carinated bul \\
\hline & body & $\mathrm{g}-\mathrm{h}$ & I/E B & F & 7.0 & Poynor Engraved el. & Carinated bow 1 \\
\hline & body & $\mathrm{g}$ & E SM & $\mathrm{G}$ & 5.7 & $\begin{array}{l}\text { hatched engraved circle, } \\
\text { cf. Poynor Engraved }\end{array}$ & \\
\hline \multirow[t]{5}{*}{ Unit 1, lv. 4} & rim & $\mathrm{g}-\mathrm{h}$ & $\mathrm{I} / \mathrm{E} \mathrm{B}$ & $\mathrm{F}$ & 6.2 & $\begin{array}{l}\text { engraved-punctated el. } \\
\text { Poynor Engraved }\end{array}$ & $\begin{array}{l}\text { D-FL, } 24 \\
\mathrm{~cm} \mathrm{OD}\end{array}$ \\
\hline & rim & $\mathrm{g}$ & I/E B & $\mathrm{C}$ & 5.2 & $\begin{array}{l}\text { horizontal and diagonal } \\
\text { engraved lines }\end{array}$ & D-FL \\
\hline & rim & $g-h$ & E SM & A & 5.2 & $\begin{array}{l}\text { single broad engraved } \\
\text { line under lip }\end{array}$ & D-FL \\
\hline & rim & $g$ & $\mathrm{I} / \mathrm{E} \mathrm{B}$ & $\mathrm{B}$ & 5.5 & $\begin{array}{l}3+\text { horizontal engraved } \\
\text { lines, closely-spaced }\end{array}$ & $\begin{array}{l}\text { INV-RO, } 19 \\
\mathrm{~cm} \mathrm{OD}\end{array}$ \\
\hline & rim & $\mathrm{g}-\mathrm{h} / \mathrm{SP}$ & E B & $\mathrm{H}$ & 6.5 & Poynor Engraved el. & $\mathrm{D}-\mathrm{RO}$ \\
\hline
\end{tabular}




\begin{tabular}{|c|c|c|c|c|c|c|c|}
\hline Provenience & Sherd & Temper & $\mathrm{ST}^{*}$ & $\mathrm{FC}$ & Th & Decoration & Comments \\
\hline & body & $\mathrm{g}$ & E B & $\mathrm{B}$ & 6.2 & $\begin{array}{l}2+\text { parallel engraved lines, } \\
\text { closely-spaced }\end{array}$ & \\
\hline & body & $g-b$ & $1 / \mathrm{E} S M$ & A & 9.6 & $\begin{array}{l}\text { opposed engraved lines, } \\
\text { Poynor Engraved }\end{array}$ & \\
\hline & body & $\mathrm{g}$ & E SM & $\mathrm{A}$ & 7.0 & opposed engraved lines & \\
\hline & body & $\mathrm{g}$ & I/E B & $\mathrm{F}$ & 6.2 & single straight engraved linc & \\
\hline & body & $\mathrm{g}-\mathrm{h}$ & EB/ISM & $\mathrm{C}$ & 5.5 & $\begin{array}{l}\text { parallel engraved lines, } \\
\text { closely-spaced }\end{array}$ & \\
\hline \multirow[t]{11}{*}{ Unit 1,1 v. 5} & rim & $\mathrm{g}$ & EB/ISM & B & 9.1 & Poynor Engraved el. & $\begin{array}{l}\text { D-RO, ext f, } \\
16+\mathrm{cm} \mathrm{OD}\end{array}$ \\
\hline & rim & $g-h$ & $\mathrm{~EB} / \mathrm{ISM}$ & $\mathrm{C}$ & 5.8 & $\begin{array}{l}\text { multiple diagonal } \\
\text { engraved lines, closely- } \\
\text { spaced }\end{array}$ & D-RO, ext f \\
\hline & rim & $\mathrm{g}$ & I/E B & $\mathrm{F}$ & 5.4 & $\begin{array}{l}3+\text { horizontal engraved } \\
\text { lines }\end{array}$ & $\mathrm{D}-\mathrm{RO}$ \\
\hline & body & $g-0$ & E B & $\mathrm{F}$ & 7.9 & $\begin{array}{l}\text { hatched engraved } \\
\text { triangles, Poynor } \\
\text { Engraved }\end{array}$ & Carinated bowl \\
\hline & body & $g-h-b$ & EB/ISM & $\mathrm{F}$ & 6.6 & $\begin{array}{l}\text { Engraved } \\
\text { hatched engraved } \\
\text { triangles, Poynor } \\
\text { Engraved }\end{array}$ & Carinated bowl \\
\hline & body & $\mathrm{g}-\mathrm{O}$ & E B & $\mathrm{G}$ & 6.4 & $\begin{array}{l}\text { horizontal and diagonal } \\
\text { engraved lines }\end{array}$ & Bottle \\
\hline & body & $\mathrm{h} / \mathrm{SP}$ & I/E SM & $\mathrm{C}$ & 6.4 & $\begin{array}{l}\text { single horizontal } \\
\text { engraved line }\end{array}$ & Carinated bowl \\
\hline & body & h-o & I/E SM & $\mathrm{H}$ & 6.8 & Poynor Engraved el. & \\
\hline & body & $\mathrm{g}$ & E B & $\mathrm{B}$ & 6.5 & $\begin{array}{l}3+\text { straight engraved } \\
\text { lines, closely-spaced }\end{array}$ & Bottle \\
\hline & body & $\mathrm{g} / \mathrm{SP}$ & E B & G & 5.4 & $\begin{array}{l}2+\text { straight engraved } \\
\text { lines, closely-spaced }\end{array}$ & $\begin{array}{l}\text { Bottle, } \\
\text { red pigment }\end{array}$ \\
\hline & body & g-h & EB/ISM & F & 6.5 & $\begin{array}{l}\text { single horizontal } \\
\text { engraved line }\end{array}$ & Carinated bowl \\
\hline \multirow[t]{6}{*}{ Unit 1, lv. 6} & rim & g-o & $1 / \mathrm{EB}$ & $\mathrm{F}$ & 8.9 & $\begin{array}{l}\text { Poynor Engraved, var. } \\
\text { Hood }\end{array}$ & D-FL, ext f \\
\hline & body & $g-b$ & I/E B & $\mathrm{B}$ & 7.2 & $\begin{array}{l}\text { singlc straight engraved } \\
\text { line }\end{array}$ & Carinated bowl \\
\hline & body & $\mathrm{g} / \mathrm{SP}$ & - & $\mathrm{C}$ & 8.9 & $\begin{array}{l}\text { single straight engraved } \\
\text { line }\end{array}$ & Carinated bowl \\
\hline & body & $g-h$ & I/E B & $\mathrm{F}$ & 7.1 & $\begin{array}{l}\text { parallel engraved lines, } \\
\text { closely-spaced }\end{array}$ & Carinated bowl \\
\hline & body & g & $\mathrm{EB}$ & G & 7.1 & $\begin{array}{l}\text { hatched engraved } \\
\text { triangle, cf. Poynor }\end{array}$ & \\
\hline & body & $\mathrm{h}$ & $\mathrm{EB} / \mathrm{ISM}$ & A & 7.4 & $\begin{array}{l}\text { Engraved } \\
\text { curvilinear engraved } \\
\text { lines, Poynor Engraved }\end{array}$ & Carinated bowl \\
\hline
\end{tabular}


44 Journal of Northeast Texas Archaeology

\begin{tabular}{|c|c|c|c|c|c|c|c|}
\hline Provenience & Sherd & Temper & $\mathrm{ST}^{*}$ & $\mathrm{FC}$ & Th & Decoration & Comments \\
\hline & body & $\mathrm{g} / \mathrm{SP}$ & I/E B & F & 5.4 & $\begin{array}{l}\text { engraved circle with } \\
\text { punctates, Poynor } \\
\text { Engraved, var. Lang }\end{array}$ & red pigment \\
\hline Unit 1, 1v. 7 & rim & $\mathrm{g}$ & $\mathrm{I} / \mathrm{E} \mathrm{B}$ & $\mathrm{H}$ & 5.6 & $\begin{array}{l}2+\text { horizontal engraved } \\
\text { lines under the lip } \\
\text { single straight engraved line }\end{array}$ & red pigment \\
\hline
\end{tabular}

*ST=surface treatment; $\mathrm{I} / \mathrm{E}=$ interior/exterior; $\mathrm{SM}=$ smoothed; $\mathrm{B}=$ burnished

FC=firing condition (see Teltser 1993:Figure 2; Perttula 2005:Figurc 5-30).

Th=thickness, in mm

$\mathrm{D}=$ direct rim; $\mathrm{EV}=$ =everted; INV=inverted; RO=rounded lip; FL=flat lip; ext $\mathrm{f}=$ =exterior folded lip

$\mathrm{OD}=$ orifice diameter

$\mathrm{g}=\mathrm{grog} ; \mathrm{h}=$ hematite; $\mathrm{b}=$ bone; $\mathrm{o}=$ charred organic material; $\mathrm{SP}=$ sandy paste 